\title{
Jewish history as a history of immigration An overview of current historiography in the Scandinavian countries
}

\author{
CHRISTHARD HOFFMANN
}

\begin{abstract}
Tistis his article provides a first critical overview of the historiography of Jewish immigration and integration in Sweden, Denmark and Norway. While the experience of immigration has been crucial for Scandinavian Jewry, scholarly interest in Jewish migration history only emerged during the 1980s in connection with the focus on migration and ethnicity in Swedish research and the adaptation of sociological concepts of migration in general historiography. By analysing key historiographical works, focusing on their approaches and main narratives, this article aims at a critical methodological self-reflection. It identifies two major approaches to Jewish immigration history in current Scandinavian historiography: the demographic and social history approach, focusing in particular on the role of Jewish immigrants in the labour market, their settlement and housing conditions and their social mobility; and the cultural history approach, reconstructing and preserving the vanished world of Yiddish immigrant culture.
\end{abstract}

\section{Introduction}

Jewish history in the Scandinavian countries (here understood as comprising of Denmark, Sweden and Norway) has been shaped considerably by the experience of migration. In Norway, the Jewish community was virtually formed only at the end of the nineteenth century when several hundred immigrants arrived from Eastern Europe. At the same time, in Denmark and Sweden, the established Jewish communities were transformed by the arrival of Eastern European Jews, and later by Jewish refugees from Central Europe.

Historical research on Jewish immigration in the Scandinavian countries gained momentum only in the mid-r 980 os, influenced by the focus on migration and ethnic history in general historiography and by the emergence of new national self-understandings of themselves as countries of immigration. From the perspective of immigration history, the Jewish experience (as the first nonChristian minority in Protestant Scandinavia) could be seen as a paradigm for contemporary developments, in particular for the integration of Muslim newcomers. The use of demographic methods and sociological concepts such as 
assimilation, integration, identity and diaspora, widened the scope of Jewish historiography and allowed for a comparison with the histories of other immigrant minorities.

This article explores this field of research by analysing key historiographical works on Jewish immigration and integration in the Scandinavian countries, focusing on their approaches and main narratives. The critical review of the historiographical development aims at an increased conceptual and methodological self-reflection and a better understanding of the internal and external factors that have shaped the scholarly perceptions and interpretations of Jewish immigration history. Since the study of history is dependent on the existence and availability of relevant primary sources (as source criticism is its most important method), the use and critical analysis of the preserved source material will be a crucial point of the methodological assessment. At the same time, the interpretation of the sources and the writing of history are not done in a vacuum. Historical narratives are often shaped by current perspectives and are written with the present day in mind. By taking into account the contemporary contexts of historiography, this article can also shed light on the changing general perceptions of migration history and Jewish history in Scandinavia since the I980s. Thematically, I will concentrate on historical works that deal with the immigration of Jews from Eastern Europe in the late nineteenth and early twentieth centuries. The history of the Jewish refugees from Nazi Germany and Nazi-occupied Europe and their reception in Sweden has found much scholarly attention in recent years. It presents, in many respects, a topic in its own right and is, for pragmatic reasons, not included in my overview. As the research of Jewish immigrants in Scandinavia has been influenced by larger trends in Jewish and European historiography, the general background of the topic will be outlined first.

\section{Migration in Jewish historiography}

When, at the beginning of the nineteenth century, modern Jewish historiography developed in Central Europe, the topic of migration was hardly included, or even mentioned at all. There were several reasons for this. The emergence of a modern Jewish historiography was closely related to the processes of emancipation and social integration of the Jews in Western and Central Europe. In Germany, for example, the integration of the Jews took place essentially as a process of integrating into the educated German middle class (Hoffmann 2003). This process ran parallel to the development of a specifically modern concept of history that gave meaning to the changes in the day-to-day world, 
legitimated these changes and thereby drove them forward. It was primarily the model of German historicism that changed the relation of Jews - or at least of a class of Jewish intellectuals at the forefront - to their own tradition: in the emerging Wissenschaft des Judenthums ('Science of Judaism') this relation was worked through and historicised along the lines of source-criticism, while the normative claim of the religious tradition was relativised (Schorsch 1994). At the same time, conceptions of time and history became more dynamic: past, present and future were experienced and interpreted as constituent parts of a comprehensive process of development (in contrast to the 'static' and typological concept of the past in traditional Jewish religious memory culture). The task of the newly emerging historiography was to represent the past in such a way that the unity of history and its 'meaning' became clear, thereby enabling purposeful action in the present. Teleological concepts, such as 'enlightenment', 'progress' and 'emancipation' were particularly prominent in this respect. The liberal narrative of Jewish history that became dominant in the nineteenth century redefined Judaism as a sort of middle-class religion of Bildung. In order to support the claim for Jewish equality and to ease the integration of Jews into the German educated middle class, it did not explore Jewish history in its entirety, but only focused on a 'respectable' selection of it. Among the topics that were left out was the Jewish experience of migration. This omission is not difficult to understand. In the polemical debates on Jewish emancipation at the beginning of the nineteenth century, the Jews were often confronted with the charge of being foreigners or even 'wandering nomads' who did not really belong to Germany (or any other European country, for that matter). To counter these attacks, Jews emphasised their long history of settlement in Germany, as did the Jewish lawyer and politician Gabriel Riesser in his famous reply to the theologian Professor Heinrich Paulus in I83 I:

The charge that our forefathers immigrated here centuries or millennia ago is as fiendish as it is absurd. We are not immigrants; we are native born.

And, since that is the case, we have no claim to a home someplace else. We are either German or we are homeless. (Mendes-Flohr and Reinharz I 995: I 44)

When at the end of the nineteenth century, modern antisemitism emerged and, in its rhetoric, employed the image of the Eastern Jewish immigrant foe who had arrived as a poor peddler and, within a few years, turned into a mighty businessman dominating the German stock market, the issue of Jewish immigration was again to haunt native Jewry. For the acculturated German Jews, 
whose pride rested on having left the ghetto behind them, the Yiddish-speaking Ostjuden, had to be representatives of the ghetto. The characterisation of the Eastern European Jews as 'ghetto Jews' can already be found in German-Jewish discourse in the middle of the nineteenth century (Aschheim I 982: $3 \mathrm{ff}$.). It is thus found at a time when the German Jews had already gone far enough into their antagonistic acculturation 'away from the ghetto' to draw a line between themselves and the apparently un-liberated, uneducated, unassimilated and socially impoverished Jews of the East. These antagonistic identity formations, constructing an intra-Jewish cultural divide between 'East' and 'West', contributed to the fact that German-Jewish historiography never really explored the history of Jewish migration - neither in the early modern period when, during the seventeenth and eighteenth centuries, many Polish and Lithuanian Jews moved to the West, nor in the contemporary period, when Eastern Jewish mass migration surged after I $88 \mathrm{I}$.

There were, of course, other reasons as well. Since most European states did not think of themselves as countries of immigration, there were no historiographical models of how to integrate the history of immigrants into a national narrative. The hegemonic nationalist perspective excluded transnational phenomena in general: the history of emigration was not systematically researched either (with the exception of Sweden). Moreover, early twentieth century historiography, both general and Jewish, was still very much concerned with the history of elite actors, both in politics and in the realm of ideas and high culture, while social history, including the history of the working class (to which many Eastern Jewish immigrants belonged), made its breakthrough only after the Second World War.

While single demographic and overview studies on global Jewish migration were published during the I940s (Kulischer I943; Lestschinsky I944; Wischnitzer I 948; see Brinkmann 201 2: I I 7; Alroey 2006), historical research on the history of Eastern Jewish immigration into Western and Central Europe only evolved in the I960s and I970s. It is striking that this field of study was mainly developed by young North American scholars, who transferred the standards and methods of American immigration history and Jewish history to their European cases. These pioneer studies include: Lloyd P. Gartner, The Jerwish Immigrant in England, 1870-1914 (1960); Nancy Green, The Pletzl of Paris: Jewish Immigrant Workers in the Belle Époque ( I 986) and Jack Wertheimer, Unwelcome Strangers: East European Jews in Imperial Germany (1987).

Based on a thorough analysis of the Hebrew, Yiddish and English sources, Gartner's work on the Eastern Jewish immigrants in England effectively challenged the hegemonic liberal narrative of Anglo-Jewish history. A Jewish 
'Whig historian', such as Cecil Roth, deliberately excluded the history of Eastern Jewish immigration from his History of the Jews in England ( I 94 I), and Vivian D. Lipman in his festschrift of the Jewish Board of Guardians (Lipman I 959) presented the role of Jewish institutions in helping their brethren from the East in the most positive light, thereby omitting their dubious role in sending them either back to Eastern Europe or further on to the United States. By contrast, Gartner explored the sensitive issue of immigration restriction within the Jewish community (see Alderman 2009). He also documented that the majority of Eastern Jewish immigrants in England were not refugees from the Russian pogroms, but migrants from Galicia who left their home towns for economic reasons. Perhaps most importantly, Gartner's study provided a model of how to write the history of an immigrant minority, exploring the causes and paths of the migration process, the political and social conditions in the receiving country, the reactions of the English and Anglo-Jewish establishment towards the newcomers and, finally, the political, social, cultural and religious history of the Eastern Jewish immigrants themselves.

While Gartner, a student of Salo W. Baron, was deeply rooted in Jewish historiography, other studies of Eastern European Jewish immigration to England were inspired by contemporary events, in particular the political debates about Commonwealth immigration in Britain during the r95os and r $960 s$. The public resentment towards Afro-Caribbean newcomers and the introduction of legislation that aimed at restricting further immigration resembled the agitation against Eastern European Jews at the end of the nineteenth century that culminated in the Aliens Act of I 905. In his book The English and Immigration 1880-1910, published in I 97 I by the Institute of Race Relations, John Garrard took the parallels between these two immigrations as a point of departure. His historical study of English, in particular left wing, reactions to Jewish immigration around the turn of the century, could thus provide insight into the presentday issue of Commonwealth immigration. The focus was thus on English reactions to immigration in general. It was not so much about popular xenophobia as such as about the ways in which immigrant restriction was framed and justified among the left-wing public. The exclusion of both Jewish and Afro-Caribbean immigrants, Garrard argued, was made more complicated because open racial prejudice was not acceptable in these quarters (Garrard I 97 I: I05ff.).

Gartner's and Garrard's books exemplify, respectively, two different approaches to the study of Jewish migration history in Europe: while Gartner is concerned with the Jewish aspects of this history - that is the cultural-religious encounters and social conflicts between native and immigrant Jews, and the resulting transformation of the Jewish community, Garrard studies the English 
aspects of this history, using the case of Eastern Jewish immigration as an historical example by which to explore English reactions towards newcomers in general. These approaches, the sectoral intra-Jewish perspective on the one hand, and the integral, and often comparative, external perspective on the other, can also be found in the historiography of Jewish migration in Scandinavia.

\section{The historiography of Jewish immigration in Scandinavia}

\section{Sweden}

In contrast to the liberal conceptions of Jewish history in Britain and Germany, Jewish historiography in Scandinavia did not totally ignore the experience of migration and the conflicts between native Jewry and Eastern European Jewish immigrants. To be sure, by focusing on Jewish emancipation and successful integration, Hugo Valentin's pioneering work on Judarnas historia i Sverige ('History of the Jews in Sweden'), published in 1924, followed the established liberal Jewish narrative. Only at the very end of his opus magnum, did Valentin briefly mention two considerably influential conditions of Jewish life in post-emancipation Sweden: increased assimilation and growing Eastern European Jewish immigration. While he referred to the negative reactions towards the immigrants, both from Swedish society in general and from established Jewry, he concluded on a conciliatory tone which suggested that there was no evidence whatsoever that the newcomers from Poland would adapt themselves less successfully or play a less significant role in Swedish and Swedish-Jewish life than those who saw themselves now as native Jews - but who actually were the descendants of earlier immigrants (Valentin I 924: 453). The experience of immigration and long-term integration was thereby inscribed as something integral to Swedish-Jewish history and identity. At the same time, the history of immigration was embedded in the master narrative of Jewish emancipation and progress.

After the Second World War and the destruction of Eastern European Jewry in the Holocaust, Valentin expanded on the history of Eastern Jewish immigrants in Sweden. In a shortened and updated version of his work, published in I964 under the title Judarna i Sverige ('The Jews in Sweden'), he explored the relationship between native Jewry and Eastern European Jewish newcomers in greater detail (Valentin I 964: I4 I-6). In particular, he pointed to the fact that Jewish communal life in the late nineteenth and early twentieth centuries would have been rather insignificant and much less vigorous without the Russian and Polish Jewish immigrants. Valentin also addressed 
the cultural and social clashes arising between the established Jewish families who adhered to the German-Jewish tradition of Bildung and their poor and supposedly uneducated brethren from the East. More clearly than in 1924, he criticised established Swedish Jewry for repressing its own history of immigration and consequently showing a lack of understanding for the situation of the newcomers:

A considerable proportion of those Jews who in our time have played, or still play, a significant role in economic and cultural life are the children or grandchildren of immigrants from Eastern Europe. The negative attitude of the old Swedish-Jewish families towards their fathers and forefathers was partly based on the contrast between assimilated and non-assimilated Jews. 'The Poles', as they generally were called, reminded the old SwedishJewish families of their own foreign origins and of a period in their history that they, however wrongly, did not like to be reminded of. In line with the general public in Sweden and Germany, they also held false and prejudiced opinions about Eastern Jewry. (Valentin I 964: I45; translated by the author)

While Valentin's clear-sighted presentation was based on the observations and experiences of his own lifetime, a thorough scholarly investigation into the topic of Eastern European Jewish immigrants and their reception by the Swedish Jewish establishment began only in the early I980s with Anna Besserman's dissertation project at the University of Stockholm. ${ }^{1}$ Based on an analysis of previously unseen sources, in particular the immigrants' applications for Swedish citizenship and the records of the Jewish community in Stockholm, Besserman studied the occupational and educational background of the Eastern European Jewish immigrants and elaborated on the social, cultural and religious differences between the established Jews who were predominantly acculturated, middle-class Reform Jews, and the newcomers who were predominantly lower class and deeply rooted in Jewish Orthodoxy and Yiddish culture. Besserman was particularly concerned to explain why the Jewish community in Stockholm, in two petitions of 1862 and 1905 to the authorities, took an initiative to restrict Eastern Jewish immigration and established a 'closed-door' policy within the community; that is, made Swedish citizenship a condition of community membership. While internal conflicts, such as for instance the wish 
to curb the influence of religious Orthodoxy or to exclude poor foreigners from the charity of the community, certainly played a role, Besserman concluded that the restrictive policy of the community also has to be seen in the context of the Jews' own insecure position within Swedish society. Faced with the negative reaction of the Swedish social environment towards the immigrants, the Jewish community felt compelled to demonstrate its loyalty and thereby try to prevent antisemitism. With growing numbers of immigrants arriving at the beginning of the twentieth century, the need for social assistance increased and was met by philanthropic societies that were later taken over by the community. The community was thereby transformed from a purely religious community into an institution with important social functions. At the same time, the norms of assimilation prevailed. It was expected that the newcomers would adapt to the norms and values of Swedish culture, in the same way that native Jewry had done before. The encounter with the immigrant brethren from the East thus demonstrated to native Jewry the limits of their own social and cultural emancipation (Besserman I 984: 36).

The impulse to explore the history of Jewish immigration in Scandinavia from an external and comparative perspective emerged largely in the context of a growing academic interest in the history of immigration and of ethnic minorities in general, which first took shape in Sweden in the late r 970s. After five years of preparation, the Centrum for multietnisk forskning (Centre for MultiEthnic Research) was established at Uppsala University in I984. Under the leadership of the historian Harald Runblom, it pioneered the study of minorities and ethnic relations in an historical and contemporary perspective. As one of the first results, a comprehensive presentation of ethnic minorities in Sweden, was published in I 988 under the title Det mangkulturella Sverige. En handbok om etniska grupper och minoriteter ('Multicultural Sweden: An Encyclopedia of Ethnic Groups and Minorities', Runblom and Svanberg 1988). It followed the model of the Harvard Encyclopedia of American Ethnic Groups (1980) and applied the concept of ethnicity as a basis for group identities. The article on the Jews, written by Harald Runblom and Matthias Tydén, included general information on Jews and Judaism as well as specific sections on the history and present situation of Swedish Jewry, as well as on antisemitism. The historical overview was informed by the categories of migration history: immigration and immigration restrictions, settlement, assimilation, the development of generations with specific experiences and identities, and not least the cultural clash between established Stockholm Jews and Eastern European immigrants, which was understood as a 'classic' conflict between older and newer immigrant groups: 
Among the Swedicised Jews there was a tendency to despise the newcomers from the East (mostly from Belarus, Poland and the Baltic countries) because they were poor, had unpolished manners, a supposedly inadequate school education and low social status. Between the groups, conflicts emerged on the religious, social and political levels. The new immigrants regarded the religious life of Swedish Jewry as shallow, while the established Jews tried, to a large extent successfully, to keep the newcomers out of the congregation and its board. (Runblom and Svanberg I988: I95; translated by the author)

The issue of Eastern European Jewish immigration was also seen as one important factor in shaping Swedish attitudes towards Jews and towards immigration in general, that is to say, in the emergence of antisemitism and of a restrictive politics towards newcomers that took shape between I9I3 and I 937 (Runblom and Svanberg i 988: r 97).

Based on the handbook, Svanberg and Tydén published a comprehensive historical overview in I 992 of the history of immigration to Sweden, entitled Tusen år av invandring. En svensk kulturbistoria ('A Millennium of Immigration: A Swedish Cultural History'). The history of Jewish immigration figured prominently in this presentation; it was seen in a comparative perspective and integrated into the history of immigration to Sweden in general. In a chapter on Jews and Catholics at the end of the eighteenth century, for instance, the changing ideological framework for the treatment of religious minorities that developed with the idea of religious freedom was taken as common ground to compare the specific conditions for Catholic and Jewish immigrants and their different paths of emancipation (Svanberg and Tydén I 992: I 80-9). Moreover the history of Eastern Jewish immigrants, their differences with native Jewry and the formation of different Jewish milieus in Stockholm (established 'Northern Jews' vs. immigrant Eastern European 'Southern Jews') were dealt with in great detail.

In her I984 article, Anna Besserman suggested that the restrictive attitude of the Stockholm Jewish community had to be understood in the context of the negative reaction of the Swedish state and Swedish majority society towards the Eastern Jewish newcomers. This topic was taken up by Carl Henrik Carlsson in his doctoral thesis on Medborgerskap och diskriminering. Östjudar och andra invandrare i Sverige 1860-1920 ('Naturalisation and Discrimination: Eastern Jews and Other Immigrants in Sweden, I 860 to I 920'), completed at Uppsala University in 2004. Based on a thorough analysis of thousands of applications for naturalisation, Carlsson documented systematic discrimination against 
Eastern Jews. The approval rate of their applications was less than fifty per cent, while that for non-Eastern Jews was almost ninety per cent. There was no other immigrant group which was to the same degree unwanted in Sweden as the Eastern Jews, who generally were associated with peddling. This discrimination was not directly linked to antisemitic or xenophobic agitation; it was rather related to the ups and downs of the economic cycle: when the economic situation improved the approval rate for Eastern Jews went up; when the economy turned sour, as in the 'long depression' between 1873 and I 896, it became very difficult for Eastern Jews to obtain citizenship, which was necessary for pursuing trade freely in Sweden. Based on his statistical material, Carlsson could also draw a more nuanced picture of the treatment of the newcomers by established Jewry. There was no doubt that the Stockholm Jewish community harboured rather negative views of the newcomers in general, but when it came to the question whether the applications of individual Eastern Jews should be recommended by the elders of the community, who served as local referees for the authorities, these recommendations were predominantly positive (74 per cent). In this way, Carlsson's solid study contributed to a more accurate picture of the dimensions and the causes of discrimination towards Eastern Jews in Sweden. Furthermore, the detailed statistical information about the newcomers that Carlsson had gathered allowed him later to analyse the specific migratory patterns of Jewish immigrants and transmigrants coming to Sweden in the period between I 870 and I 920 (Carlsson 2013).

The processes of Jewish identity formation and assimilation have often been described exclusively in terms of religious (Reform vs. Orthodoxy) or political (Liberal-Socialist-Zionist) identity markers. In her innovative study Judiskt liv i Stockholm och Norden. Ekonomi, identitet och assimilering 1850-1930 ('Jewish Life in Stockholm and the Nordic Countries: Economy, Identity and Assimilation, I850-1930') the economic historian Rita Bredefeldt chose a different approach, focusing on the role of Jews in economic life as a decisive factor for Jewish identity and assimilation. Based on fresh sources, in particular the tax and electoral registers of the Stockholm Jewish community, Bredefeldt drew a new and more precise picture of Jewish adaptation strategies, the participation of Jewish women in the labour market, and not least, the integration of Eastern European Jewish immigrants. It showed that the identity formation that had been crucial for the integration of Western Jews in Sweden during the eighteenth and early nineteenth centuries, and that was defined by the ideals of economic success, benefits to society and self-cultivation (Bildung) as a strategy of winning social acceptance, also shaped the ways of integration for the Eastern Jewish immigrants who originally were mainly craftsmen and industrial workers. 
Most Eastern Jewish immigrants were integrated into the Swedish social economy and in principle took over the Western Jewish self-image of the economic successful and cultivated Swedes of the Jewish faith. Upward social mobility now found its expression in the efforts of the younger generation to obtain academic careers and to educate themselves for 'useful' occupations that were always in demand. Over time, the Eastern Jewish immigrants and their descendants became the majority of Jews in Sweden. By then, they had taken over the definition of Jewish identity developed by their predecessors. (Bredefeldt 2008: 78; translated by the author)

Bredefeldt explained the pressure to assimilate and lack of pluralism by pointing to the forces of antisemitic prejudice in Swedish society that saw all Jews as one collective group regardless of their real social, religious and cultural differences. Jews reacted to that by choosing a strategy of cautiousness and defensive self-assertion. In such a climate, there was little room for the development of different Jewish identities. Bredefeldt's conclusion on this point thus confirmed the view of Hugo Valentin in I924, quoted earlier in this article, which had emphasised the path of emancipation and integration of Western Jews in Sweden as a model for the Eastern Jewish immigrants (Valentin I 924: 453).

\section{Denmark}

In the decades preceding the First World War, the Danish capital became the city of arrival for several thousand Russian Jewish immigrants. While many of them were transmigrants and moved on to England and the USA, around three thousand settled permanently in Copenhagen. The history of this community has been researched, documented and narrated by two different historians: Bent Blüdnikow, in his pioneering and popular book of I 986 , Immigranter. De osteuropeiske jøder i København 1905-1920 ('Immigrants: The Eastern European Jews in Copenhagen, I905-20') which focuses on the peak of Jewish immigration before the First World War, while Morten Thing in his voluminous cultural history, published in 2008, De russiske Jøder in København 1882-1943 ('The Russian Jews in Copenhagen r882-I943') took a broader chronological and thematic perspective.

Critical of what he regarded as the apologetic and bourgeois character of established Danish-Jewish historiography and its emphasis on the cultural contributions of eminent Danish Jews, Blüdnikow developed an historical interest in the Jewish lower classes, the Jewish poor and, in particular Jewish 
immigrants from Eastern Europe (Blüdnikow 1987). He argued that the impact of Copenhagen Jewry on Danish society in the eighteenth century was probably founded more on Jewish pawnbrokers and dealers of second-hand clothes than on Jewish poets or financiers (Blüdnikow I 988: 243). His history of the Eastern European Jewish immigrants in Copenhagen was influenced by the same perspective: it was written as a kind of counter-history to the established narrative of Danish-Jewish history shaped by the norms of assimilation and middle-class respectability. Based on a variety of sources, including the archives of the state police and the Jewish community, and illustrated by some interviews with immigrants themselves and by many photographs from private collections, it brought to life the vanished and mostly forgotten world of immigrant working-class culture in Copenhagen which had flourished in the decade before the First World War. In its approach, it was inspired by Irving Howe's classic memorial book of I 976; World of Our Fathers: The Journey of the East European Jews to America and the Life They Found and Made and by the general interest in social history and working class culture in the r970s and i 980 os. Blüdnikow carefully reconstructed the legal and social framework conditions for the immigrants. These were determined by the state authorities and, with respect to poor relief, by the Jewish community, and became more difficult during the First World War. Still, Blüdnikow did not present the immigrants as mere victims of these circumstances, but stressed their agency and initiative by making visible their rich organisational and cultural life. In this way, he introduced the voices and perspectives of the immigrants themselves into Danish-Jewish historiography and tried to portray the immigrant 'ghetto' of Copenhagen as an important site of Jewish history and of socialist workingclass culture. Being a descendant of an immigrant family himself, Blüdnikow tried to convey a view from the inside of the Eastern European Jewish milieu in Copenhagen. His book can be characterised as a mixture of academic historiography and memorial heritage literature.

While Blüdnikow's popular book had a clear message and was written with personal involvement, Morten Thing's study of the Russian Jews in the Danish capital was much more academic in character. Based on many years of meticulous research, especially a first analysis of the comprehensive source material written in Yiddish, Thing's cultural history of the Russian Jewish immigrants was clearly superior in terms of the breadth, depth and solidity of his presentation. The encyclopedic treatment of the topic in a volume of 656 large format pages, on the other hand, made it more difficult for the reader to discern a common thread of interpretation. The compartmentalisation of various subtopics, the richness of detail and the lack of an overriding narrative made the book 
as much a work of reference as one of historiography. To be sure, in the introduction Thing outlined an interpretational framework by applying the sociological concepts of integration and assimilation to the history of the Russian Jewish immigrants and thereby distinguished three different phases: the period between I 882 and I 920 when the immigrants developed their separate cultural identity 'with a fantastic vitality' (Thing 2008: 22); the inter-war years when most immigrants became integrated into Danish-Jewish and thereby Danish society - a process that led from bi-culturalism to assimilation; and finally the years after the Second World War, only briefly covered in the epilogue of the book, when the assimilation process became complete and the remnants of Yiddish culture faded away. But this frame of interpretation is not systematically applied throughout the book, the second part of which deals with the reactions of Danish society to the immigrants and the development of Danish antisemitism. Thing's opus magnum about the Yiddish speaking immigrants in Copenhagen has no equivalents in other Scandinavian countries and can be seen as a scholarly monument of a vanished immigrant culture whose native ground had been brutally destroyed in the Holocaust.

\section{Norway}

The first and most comprehensive academic work on the history of Jews in Norway, Oskar Mendelsohn's Jødenes bistorie i Norge gjennom 300 àr ('The History of the Jews in Norway over 300 Years'), was published in two volumes in I 969 and I986. Based on an intensive study and documentation of the sources, Mendelsohn's work followed a double track: the external (legal, political and social) structural conditions of Jewish presence and life in Norway; and the development of the Jewish minority and the internal life of its communities. While Mendelsohn carefully listed all families who immigrated to Norway before I900, including the children born in Norway up to the same year, his presentation was not really a history of Jewish immigration. It lacked the methodological tools and the analytical categories that could have extracted a meaningful historical narrative out of the enormous amount of raw material (e.g., Mendelsohn r 969: 276-306, 327-404; see Hoffmann 201 3: 246-9).

In Norway, the history of Jewish immigration was first systematically researched in connection with the project of the Norsk innvandringshistorie ('Norwegian History of Immigration'), developed and carried out by Knut Kjeldstadli and Jan Eivind Myhre in the years I 998-2003 (Kjeldstadli 2003, II: 278-85, 408-I 4; III: 27-39). 
Martha Gjernes's study of 2002 on the settlement and socio-economic placement of Jewish immigrants in Christiania during the period I $85 \mathrm{I}-\mathrm{I} 942$, originated from this project and was the first to apply the methods of social historical research on the Jewish minority in Norway (Gjernes 2004, 2007). Having collected comprehensive information on Jewish immigrants onto a database, she applied a framework of socio-historical analysis and could thus present new findings about the scope and phases of Jewish immigration, the origins of the immigrants and their demography and social structure, their employment and position in Norwegian working life and, not least, their settlement and housing conditions in the Norwegian capital. Based on the statistical data of her study, Gjernes was able precisely to locate the Jewish immigrant community within the Norwegian labour market and thus arrived at new conclusions about their specific group behaviour and their collective strategies of integration:

[We have witnessed] how the Jewish immigrants actively responded and related to their situation in the workforce. The fact that as a group they placed themselves into a niche in the labour market also led to cohesion within the ethnic group in the economic sphere. Working independently, they established small networks, especially through families. Both the cohesion of the group and cohesion within the family can be understood as responses to the problem of gaining access to the labour market, as well as offering protection against the fluctuations there. The positive appeal of the community was equally important, as well-established Jews helped newly immigrant Jews. The independent nature of the work also allowed for a greater degree of autonomy. This kind of ethnic concentration around a segment of the labour market did not, however, lead to isolation. The Jewish network aided many in landing on their feet in the labour market, which was necessary in getting a standing in society at large. (Gjernes 2007: I4I; translated by the author)

Gjernes painted a picture in which a minority - because of its specific vocational structure, focused around trade - was highly visible in Norwegian society. Considering the hostility of the external society, especially towards the peddling of goods, the internal network and the internal cohesion of the community were important in establishing an economic footing, as well as for survival. A strategy of assimilation - that is, of being completely absorbed by Norwegian society - was not a possibility in this context. The Jews in Norway wanted to preserve their Jewish identity, while at the same time having to take into consideration the reservations of the majority society, and therefore adopted a 
strategy of 'careful integration' into Norwegian society. Similar to the integration of Eastern Jewish immigrants in Sweden analysed by Bredefeldt, Jews in Norway integrated by climbing the social ladder, as well as by means of education and through the acquisition of bourgeois values. Their new identity as 'successful Norwegian Jews' was to replace the stigmatised image of the peddler of goods. At the same time, through mutual assistance and internal policing, the Jewish community attempted to avoid offending the majority culture, and in this way to come to terms with antisemitic accusations.

Gjernes's social history of Jewish immigration to Oslo can be seen as a narrative of integration in two different ways: firstly because of its focus on the immigrants' integration into Norwegian working life; secondly because of its attempt to integrate the history of the Jewish minority into Norwegian national history, or more precisely, into Norwegian labour and immigration history. The thematic concentration on the working life and the use of quantitative methods of social history conveyed a new picture of the Jewish minority and made it more similar (and comparable) to other social and ethnic immigrant groups in Norway. As a result, the perspective of Jewish historiography in Norway became broader: it not only saw the history of the Norwegian Jews under the shadow of 1942 (which saw the deportation and murder of over one third of the Jews in Norway), but also emphasised the 'normality' of Jewish life before the Holocaust - as immigrants and as an ethnic-religious minority within Norwegian society.

In a recent article, Vibeke Kieding Banik supplemented Gjernes's social history of Jewish immigration and integration in Norway with a special study of the participation of Jewish women in the labour market and its significance for the integration of Jews in Norway (Banik 2015). Analysing not only official census data, including the special questionnaire for Jews issued by the Nazi government in 1942 , but also biographical sources and interviews, she produced more nuanced results and concluded that Jewish women in Oslo were well integrated into the labour market; their (full-time) employment rate was similar to that of their non-Jewish peers of the same social class (nearly one third in r 9 ro, and as high as 40 per cent in 1942). While most women in the labour market were unmarried, also married women, mostly categorised as homemakers, were economically active as entrepreneurs, in family enterprises or as breadwinning wives, securing additional income. Female participation in the labour market increased with the second generation of immigrant Jews that had grown up in Norway. Banik explained this development mainly by pointing to the economic conditions in Norwegian society: 
Women worked mainly because their family needed their income, and Oslo was an expanding city where retailers and retail workers were in demand. Once an informal network of Jewish retailers was established, the next generation could rely on relatives and acquaintances for training and work if means of income in other places failed. (Banik 20 I 5: 197)

Banik's results differed considerably from those of Bredefeldt's study on the gender aspects of Jewish social mobility in Stockholm (Bredefeldt 2008: 83-I I6). In contrast to Banik, Bredefeldt had found a decline in female participation in the labour market and explained it by a common strategy of advancement, a kind of 'gender contract' attributing the sphere of labour to the man and the domestic sphere of education and the preservation of the religious-cultural tradition to the woman (ibid. I I 4). Unfortunately, Banik, despite the comparative perspective of her article, did not take Bredefeldt's relevant findings into consideration, let alone discuss possible explanations for the different developments in Norway and Sweden.

\section{Conclusion}

The findings of this historiographical overview may be summarised as follows. Scholarly interest in the history of Eastern Jewish immigration to Western Europe gained momentum only in the r 980 s. It was invoked and influenced by general changes and innovations in the study of history, above all the rise of ethnic and cultural studies in the United States and of social history in Europe. Both established class, gender and ethnicity as central categories of historical analysis. From the perspective of national historiography, the history of Jewish immigration in the nineteenth and early twentieth centuries was seen as an early example of contemporary, colonial or guest-worker immigration and was studied in order to explore general patterns of state and majority responses to newcomers, and of minority integration into majority society. From the perspective of Jewish historiography, the focus on Jewish experiences of immigration to the United States or Europe indicated a reappraisal of the history of the diaspora. Vis-à-vis the Zionist catchphrase of 'assimilation as Jewish selfdenial', the sociological concepts of acculturation, identity, subculture and, later, diaspora, allowed for a more accurate and nuanced description of the processes of incorporation and Jewish self-assertion. At the same time, the apologetically motivated 'blind spots' of previous Jewish historiography, glossing over internal conflicts and the discrimination of Eastern European newcomers, were gradually confronted by independent research. With the emergence of cultural 
history at the end of the twentieth century, the historical Jewish minority in Europe, and, in particular the German Jews, could be seen as 'models of hybridised identity, and as guides to a specifically modern diasporic existence' (Moyn I 996: 308).

Also in the Scandinavian countries the study of Jewish history has been enriched by the perspectives of migration research and multi-ethnic history. The scholarly interest in Jewish migration history developed first in Sweden during the I980s, as part of a new multicultural understanding of national history and the institutionalisation of multi-ethnic studies at the University of Uppsala. In Denmark and Norway, by contrast, research in Jewish migration history came rather late, was not institutionalised at a university and thus more dependent on the personal initiative of individual scholars.

The dominant approach of Jewish immigration history in Scandinavia, most clearly seen in Swedish and Norwegian historiography, was shaped by the conceptual framework of social history and ethnic relations. It aimed at exploring both - the reactions of the state and of majority society toward the newcomers, and the history of the Jewish immigrant minority, its specific strategies of integration and forms of identity, in comparison with other minority groups. Methodologically anchored in demography and sociology, informed by the concepts of migration studies and based on the rich source material that allowed for statistical analysis on a micro-level, these approaches largely focused on the role of the Jewish immigrants (men as well as women) within the labour market, their settlement and housing conditions and their social mobility. The Jewish minority was researched with the same analytical tools taken from the social sciences as other social groups and was thereby integrated into general historiography. The relationship between Jews and non-Jews in these studies was often interpreted as based in social conditions. Conflicts between majority and minority that had found its expression in rising anti-Jewish hostility or discrimination were largely attributed to social causes; for instance economic recession or rivalry. In the same way, the internal Jewish conflicts between an assimilated Jewish bourgeoisie and poor Eastern Jewish immigrant workers were explained by the class difference and the perceived loss of status for the established Jews, whereas religious and cultural differences were only considered to be of secondary significance. On the other hand, the long-term function of established Jewry as a kind of sluice of integration for the newcomers was emphasised, in particular by Bredefeldt.

An alternative approach could be found in the historiography of the Russian Jews in Copenhagen. To be sure, Blüdnikow and Thing, regardless of their differences, also researched the external political and societal framework conditions 
of the immigrants and outlined processes of integration and assimilation, but the main emphasis was clearly on the social and cultural life of the immigrants themselves. The vitality of Yiddish immigrant culture in the Danish capital was reconstructed with a loving care for details, especially by Thing. The immigrants were here not presented as passive victims of trying circumstances, but portrayed in their historical agency and with their, often polyphonic, original voices and pluralistic identities. Since Yiddish culture today has almost completely disappeared - wiped out in Eastern Europe by the destruction of Jewish life during the Holocaust and vanished in the West as a consequence of assimilation - these histories aimed at preserving its legacy for posterity.

The different approaches towards the study of Jewish immigration history identified in this overview can be attributed to different disciplinary traditions (social history vs. cultural history), different views of Jewish history in general (external vs. internal perspectives) and not least to the simple fact that Yiddish immigrant culture in Copenhagen was more significant and has left richer source material than that in Stockholm or Oslo. The clear dominance of the social history approach in Scandinavia can be largely explained by the strong position of economic and social history in general historiography. But it may also reflect a lack of knowledge of the Yiddish language and of familiarity with Jewish culture in general among Scandinavian historians of migration, which makes them shy away from religious or cultural topics. In order to further develop this fascinating field of research, it therefore seems necessary to combine the external and the internal perspectives of Jewish migration and explore their interconnectedness in greater detail.

Christhard Hoffmann is Professor of Modern European History at the University of Bergen. He has developed special research interests in the history of migration and minorities; antisemitism and Jewish history; the public uses of history and memory. His main publications include: Juden und Judentum im Werk deutscher Althistoriker des 19. und 20. Jahrhunderts (1988, reprint 2007); Exclusionary Violence: Antisemitic Riots in Modern German History (co-editor 2002); Preserving the Legacy of German Jewry: A History of the Leo Baeck Institute, 1955-2005 (editor 2005); Antisemitism in Norway? The Attitudes of the Norwegian Population towards Jews and other Minorities (co-editor, 2013).

\section{References}

Alderman, Geoffrey, 2009. 'The Canon: The Jewish Immigrant in England I 870-I 9I4, by Lloyd P. Gartner', Times Higher Education, 29.5.2009

Alroey, Gur, 2006. 'Demographers in the service of the nation: Liebmann Hersch, Jacob Lestschinsky, and the early study of Jewish migration', Jewish History, $20(3-4)$, pp. $265^{-82}$ 
Aschheim, Steven E., 1982. Brothers and Strangers: The East European Jew in German and German Jewish Consciousness, 1800-1923 (Madison, The University of Wisconsin Press)

Banik, Vibeke Kieding, 20 I 5. 'A gendered integration revisited: work and integration of Jews in Norway, I 900-1 942', Modern Judaism, 35(2), pp. I 75-97

Besserman, Anna, I 984. “....eftersom nu en gång en nådig försyn täckts hosta dem upp på Sveriges gästvänliga stränder.' Mosaiska församlingen i Stockholm inför den östjudiska invandringen till staden I 860-I 9 I 4, Nordisk Judaistik, 5, pp. I3-38

Blüdnikow, Bent, I 986. Immigranter. Østeuropæiske jøder i København 1904-1920 (København, Borgen)

- 1987. 'Fattig, fremmed og forvist. Illegale jøder i Danmark' in Fremmede i Danmark. 400 års fremmedpolitik, ed. Bent Blüdnikow (Odense Universitetsforlag), pp. 47-72

—_ 1988. 'Østeuropeiske jøder i København I 904-I920' in Judiskt liv i Norden, eds Gunnar Broberg, Harald Runblom and Mattias Tydén, Studia Multiethnica Upsaliensia, 6 (Uppsala universitet), pp. 243-57

Bredefeldt, Rita, 2008. Judiskt liv $i$ Stockholm och Norden. Ekonomi, identitet och assimilering 1850-1930 (Stockholm, Stockholmia)

Brinkmann, Tobias, 20I 2. Migration und Transnationalität, Perspektiven deutschjüdischer Geschichte (Paderborn, Schöningh)

Carlsson, Carl Henrik, 2004. Medborgerskap och diskriminering. Östjudar och andra invandrare i Sverige 1860-1920, PhD dissertation (Uppsala University)

-2013. 'Immigrants or transmigrants? Eastern European Jews in Sweden, I 860-I 9 I4' in Points of Passage: Jewish Transmigrants from Eastern Europe in Scandinavia, Germany, and Britain 1880-1914, ed. Tobias Brinkmann (New York, Berghahn Books), pp. 47-62

Garrard, John I 97 I. The English and Immigration 1880-1910 (Oxford University Press)

Gartner, Lloyd P., I 960. The Jewish Immigrant in England, 1870-1914 (London, George Allen \& Unwin)

Gjernes, Marta, 2004. 'Dei fyrste jødiske innvandrarane i Kristiania', Historisk Tidskrift, 83, pp. 385-4I 6

-2007. Jødar i Kristiania. Dei fyrste innvandrarane si geografiske og sosioøkonomiske plassering i samfunnet frå 1851 til 1942 (Oslo, HL-senteret)

Hoffmann, Christhard, 2003. 'Die Verbürgerlichung der jüdischen Vergangenheit. Formen, Inhalte, Kritik' in Judentum und Historismus. Zur Entstehung der jüdischen Geschichtswissenschaft in Europa, ed. Ulrich Wyrwa (Frankfurt/M., Campus), pp. I49-7I

-2013. 'Nasjonalhistorie og minoritetshistorie. Jødisk historiografi i Norge' in Fortalt fortid. Norsk historieskriving etter 1970, eds Jan Heiret, Teemu Ryymin and Svein Atle Skålevåg (Oslo, Pax), pp. 240-63

Kjeldstadli, Knut (ed.), 2003. Norsk innvandringshistorie, 3 vols (Oslo, Pax) 
Kulischer, Eugen M., I943. Jewish Migrations: Past Experiences and Post-War Prospects (New York, American Jewish Committee)

Lestschinsky, Jacob, I 944. Jerwish Migration for the Past Hundred Years (New York, YIVO)

Lipman, Vivian, 1959. A Century of Social Service, 1859-1959: The Jewish Board of Guardians (London, Routledge and Kegan Paul)

Mendes-Flohr, Paul, and Jehuda Reinharz (eds), r 995. The Jew in the Modern World: A Documentary History, 2nd edn (Oxford University Press)

Mendelsohn, Oskar, I 969. Jødenes Historie i Norge gjennom 300 år, bind I (Oslo, Universitetsforlaget)

Moyn, Samuel, I 996. 'German Jewry and the question of identity: historiography and theory', Yearbook of the Leo Baeck Institute, 4 I, pp. 29 I-308

Runblom, Harald, and Ingvar Svanberg (eds), i 988. Det mångkulturella Sverige. En handbok om etniska grupper och minoriteter (Stockholm, Gidlunds)

Schorsch, Ismar, I 994. From Text to Context: The Turn to History in Modern Judaism (Hanover and London, Brandeis University Press)

Svanberg, Ingvar, and Mattias Tydén, I 992. Tusen år av invandring. En svensk kulturbistoria (Stockholm, Gidlunds)

Thing, Morten, 2008. De russiske jøder i København 1882-1943 (København, Gyldendal)

Valentin, Hugo, I 924. Judarnas historia i Sverige (Stockholm, Bonniers)

- i 964 . Judarna i Sverige (Stockholm, Bonniers)

Wischnitzer, Mark, I 948. To Dwell in Safety: The Story of Jewish Migration since 1800 (Philadelphia, Jewish Publication Society) 